THE MISSING LINKS IN TEACHER EDUCATION DESIGN 


\section{Self Study of Teaching and Teacher Education Practices}

Volume 1

Series Editor

John Loughran, Monash University, Clayton, Australia

Advisory Board

Mary Lynn Hamilton, University of Kansas, USA

Ruth Kane, Massey University College of Education, New Zealand

Geert Kelchtermans, University of Leuven, Belgium

Fred Korthagen, IVLOS Institute of Education, The Netherlands

Tom Russell, Queen's University, Canada 


\title{
THE MISSING LINKS IN TEACHER EDUCATION DESIGN
}

Developing a Multi-linked Conceptual Framework

\author{
Edited by
}

Garry F. Hoban

University of Wollongong,

NSW, Australia

焦 Springer 
A C.I.P. Catalogue record for this book is available from the Library of Congress.

ISBN-10 1-4020-3338-9 (HB) Springer Dordrecht, Berlin, Heidelberg, New York ISBN-10 1-4020-3346-X (e-book) Springer Dordrecht, Berlin, Heidelberg, New York ISBN-13 978-1-4020-3338-4 (HB) Springer Dordrecht, Berlin, Heidelberg, New York ISBN-13 978-1-4020-3346-9 (e-book) Springer Dordrecht, Berlin, Heidelberg, New York

Published by Springer,

P.O. Box 17, 3300 AA Dordrecht, The Netherlands.

Cover image by Karl Mutimer from EmLab at the University of Wollongong.

Printed on acid-free paper

All Rights Reserved

(C) 2005 Springer

No part of this work may be reproduced, stored in a retrieval system, or transmitted in any form or by any means, electronic, mechanical, photocopying, microfilming, recording or otherwise, without written permission from the Publisher, with the exception of any material supplied specifically for the purpose of being entered and executed on a computer system, for exclusive use by the purchaser of the work.

Printed in the Netherlands. 


\section{DEDICATION}

To my mother, Olive, who has always been my inspiration and comfort 


\section{Contents}

List of Figures and Tables $\quad$ xi

List of Contributors xiii

Series Editor's Foreword xix

\section{Introduction}

1. Developing a Multi-linked Conceptual Framework for Teacher Education Design

Garry F. Hoban

\section{PART I. Conceptual Links Across the University Curriculum}

Introduction

Garry F. Hoban

2. Principled Practice in Teacher Education

Vicki Kubler LaBoskey

3. Evolution from a Problem-Based to a Project-Based Secondary Teacher Education Program: Challenges, Dilemmas and Possibilities

Peter Aubusson

4. On Discernment: The Wisdom of Practice and the Practice of Wisdom in Teacher Education Anne M. Phelan

5. Re-Organising and Integrating the Knowledge Bases of Initial Teacher Education: The Knowledge Building Community Program

Julie Kiggins, Brian Cambourne \& Brian Ferry

6. Teacher Education for the Middle Years of Schooling: Making Connections between Fields of Knowledge, Educational Policy Reforms and Pedagogical Practice Jane Mitchell, Lisa Hunter, Lisa Patel Stevens \& Diane Mayer 
PART II. Theory-Practice Links between School and University Settings

Introduction

Garry F. Hoban

7. Innovation and Change in Teacher Education: An Inquiring, Reflective, Collaborative Approach

Anne Reilley Freese

8. Using the Practicum in Preservice Teacher Education Programs: Strengths and Weaknesses of Alternative Assumptions about the Experiences of Learning to Teach Tom Russell

9. Who Stays in Teaching and Why?: A Case Study of Graduates from the University of Kansas' 5th-Year Teacher Education Program

Pam Green, Mary Lynn Hamilton, James K. Hampton and Margie Ridgeway

PART III. Social-Cultural Links amongst Participants in the Program

Introduction

Garry F. Hoban

10. Constructing and Sustaining Communities of Inquiry in Teacher Education

Gaalen Erickson, Linda Farr Darling and Anthony Clarke

11. Developing a Culture of Critique in Teacher Education Classes John Loughran, Amanda Berry and Elizabeth Tudball

12. Community-Building and Program Development go Hand-inHand: Teachers Educators Working Collaboratively

Clare Kosnik and Clive Beck

\section{PART IV. Personal Links that Shape the Identity of Teacher}

\section{Educators}

Introduction 
13. The Quest for Identity in Teaching and Teacher Education Robert V. Bullough, Jr.

14. Identity Development, Moral Authority and the Teacher Educator

Stefinee Pinnegar

\section{Conclusion}

15. Using a Multi-Linked Conceptual Framework to Promote Quality Learning in a Teacher Education Program Garry F. Hoban 


\title{
List of Figures and Tables
}

\author{
FIGURES
}

3.1. Modified program structure. 51

4.1. The master of teaching program. 59

4.2. MT program, year 1, campus and field schedule (Faculty of Education, 2003).

$\begin{array}{ll}\text { 5.1. Session-by-session progression. } & 79\end{array}$

5.2. Diagramatic representation of the KBC's learning principles. 82

5.3. The four pillars of professional learning \& the KBC processes and structures of integration. $\quad 86$

5.4. The knowledge integration process. 91

6.1. Theory of pedagogy diagram. 109

A. Key ideas to promote conceptual links across the university
curriculum.

B. Key ideas to promote conceptual and theory-practice links. $\quad 170$

C. Key ideas to promote conceptual, theory-practice and
social-cultural links.

15.1. A multi-linked conceptual framework for teacher education design.

\section{TABLES}

8.1. Comparison of two approaches to the preservice practicum in teacher education.

8.2. One row selected from installment 4 of the story assignment. 148 


\section{List of Contributors}

Peter Aubusson is Associate Professor in Science Teacher Education at University of Technology Sydney where he belongs to the Teacher Learning and Development Research Group (TLD). He was a school science teacher for over ten years during which time he researched his own practice. His current research interests include analogical thinking, teacher professional learning, and investigations with teachers to try 'new' strategies and approaches. His research interest in teacher education began in the early 1990s and his studies include initial and post initial teacher education. Peter proposed using chain links for the cover.

Clive Beck is Professor in the Centre for Teacher Development and the Department of Curriculum, Teaching and Learning at OISE/University of Toronto. He is past-president of the Philosophy of Education Society. He teaches graduate courses on teacher research, teacher development, and school renewal. In the Mid-Town elementary preservice program he teaches social foundations and supervises practice teaching and action research. His books include Educational Philosophy and Theory and Better Schools. His main areas of research are preservice teacher education and social constructivism in teaching and teacher education.

Amanda Berry is a Senior Lecturer in Education at Monash University where she works mainly in the areas of preservice and inservice science teacher education. Amanda's research focus is the self-study of teaching practice, an interest that began during her career as a high school science teacher, before joining Monash University. She has a keen interest in the collaborative learning about teaching that can take place between teacher education colleagues and in the power of modelling in teaching about teaching.

Robert V. Bullough, Jr. is Professor of Teacher Education in the McKay School of Education and Associate Director for Teacher Education Research, Center for the Improvement of Teacher Education and Schooling (CITES), Brigham Young University. He is Emeritus Professor of Educational Studies, University of Utah. His most recent book is Uncertain Lives: Children of Promise, Teachers of Hope (New York: Teachers College Press). 
Brian Cambourne is an Associate Professor at the University of Wollongong. $\mathrm{He}$ has an interest in promoting quality teaching within the Faculty of Education at the university and using alternative approaches to teacher education.

Anthony Clarke is an Associate Professor in the Department of Curriculum Studies at the University of British Columbia where he holds a position as a 'teacher educator' with research interests in self-study, the practicum, and supervision.

Gaalen Erickson is a Professor at the University of British Columbia and Director of the Centre for the Study of Teacher Education.

Linda Farr Darling is an Associate Professor at the University of British Columbia and a key person in their Community of Inquiry in Teacher Education program.

Brian Ferry is Associate Dean Graduate at the University of Wollongong. His research interests are information technology in education and alternative approaches to initial teacher education.

Anne R. Freese is a Professor in the Department of Curriculum Studies at the University of Hawaii. She served as Director of the Master of Education in Teaching (MET) Program and taught in the program for eight years. Her research interests include self-study of teacher education practices, teacher research, reflective practice, and school-university partnerships.

Pam Green is a Ph.D. candidate at the University of Kansas in the Department of Teaching \& Leadership, with a concentration in the area of Curriculum \& Instruction. She previously taught home economics, and also served as a Child Nutrition Programs Consultant at the Oklahoma State Department of Education.

Mary Lynn Hamilton is an Associate Professor in the Department of Teaching and Leadership at the University of Kansas where her research focuses on teachers' professional knowledge and issues of social justice.

James K. Hampton is the Assistant Professor of Youth Ministry at Asbury Theological Seminary in Wilmore, KY. He is a Ph.D. candidate at the University of Kansas, where his studies have centered on the foundations of education.

Garry F. Hoban is a Senior Lecturer and director in the Faculty of Education at the University of Wollongong, NSW Australia. His research interests include 
technology enhanced professional learning for inservice teachers and reflective practice for preservice teachers. He is the author of Teacher Learning for Educational Change: A Systems Thinking Approach (Open University Press, 2002) and is the editor of this book.

Lisa Hunter is a researcher in the areas of young people, middle years of schooling, embodiment and physical culture, and health and physical education. She holds a joint appointment in the School of Education and School of Human Movement Studies at the University of Queensland, lecturing in the Middle Years of Schooling Teacher Education program.

Fred Korthagen is a Professor of Education at the IVLOS Institute at Utrecht University, the Netherlands. He specializes in the relation between the professional and the personal aspects of teaching. More information about Fred Korthagen and his publications is available on http://www.ivlos.uu.nl/deorganisatie/wiewatwaar/medewerkers/korthagen/ 6795main.html

Julie Kiggins is a Lecturer in the Faculty of Education at the University of Wollongong. She coordinates an alternative teacher education program called the KBC (Knowledge Building Community-Mentor Program)

Clare Kosnik is Executive Director of the Teachers for a New Era project at Stanford University. Previously, she was Associate Professor in the Department of Curriculum, Teaching and Learning at the Ontario Institute for Studies in Education, University of Toronto, and Director of the Elementary Preservice Program at OISE/UT. Professor Kosnik is currently Chair-Elect of the Self-Study of Teacher Education Practices Special Interest Group of the American Education Research Association. She is co-editing the upcoming Kluwer text: Making a difference in teacher education through self-study: Studies of personal, professional, and program renewal.

Vicki Vubler LaBoskey is a Professor of Education at Mills College in Oakland, CA where she co-directs the Teachers for Tomorrow's Schools Credential Program. She received her Ph.D. from Stanford University in Curriculum and Teacher Education. She is President of the California Council on Teacher Education and also Chair of the American Education Research Association's Special Interest Group, Self-Study of Teacher Education Practices. She is one of the four editors of the International Handbook of Self-Study of Teaching Practice published by Kluwer in April of 2004.

John Loughran is the Foundation Chair of Curriculum and Professional Practice in the Faculty of Education at Monash University. His research interests 
include science teacher education, teacher-as-researcher and reflective practice. He is the Past-President of the Self-study of Teacher Education Practices SIG of AERA and is co-editor of the International Handbook of Teaching and Teacher Education Practices (Kluwer).

Diane Mayer's research interests include teacher education, teachers' work, teacher professional learning, and professional standards for teachers. She provided leadership in teacher education in at the University of Queensland and the University of Southern Queensland for fifteen years prior to moving to the University of California at Berkeley in 2004.

Jane Mitchell is a Senior Lecturer in the Faculty of Education at Monash University having previously held positions at the University of Queensland and Charles Sturt University. Her research interests focus on pedagogy and curriculum in teacher education.

Anne M. Phelan is an Associate Professor in the Faculty of Education at the University of British Columbia. Her research interests are teacher education and curriculum studies. She has published in a variety of journals including Teaching and Teacher Education, Studies in Philsophy and Education and Curriculum Inquiry. She is currently leading a study of the initial education of teachers, nurses, physicians and social workers entitled "Discourses of Conflict: A Multidisciplinary Study of Professional Education."

Stefinee Pinnegar is an Associate Professor of teacher education at Brigham Young University. Her work focuses on self-study and teacher education. Her interest in teacher education is the development of practical memory for teaching. In self-study she works on the methodology of self-study and uses it to improve her own practice as a teacher educator.

Margie Ridgeway teaches English, Spanish, ESL, and Special Education at Bert Nash School, at the Atchison Juvenile Correctional Facility in Atchison, KS. She is a Ph.D. candidate at the University of Kansas, with a major in TESOL (teaching English to speakers of other languages) and a minor in Indigenous Nations Studies.

Tom Russell is a Professor in the Faculty of Education of Queen's University, Kingston, Ontario, Canada. His teaching includes secondary science methods, action research and reflective practice, and pre-service practicum supervision, while his research focuses on how individuals learn to teach. He is a coeditor of the International Handbook of Self-Study of Teaching and Teacher Education Practices and Improving Teacher Education Practices through SelfStudy. 
Lisa Patel Stevens is a lecturer in the Middle Years of Schooling Teacher Education program at the University of Queensland. Her research interests include digital literacies, the cultural construction of adolescence, and the intersections of language, literacy and culture.

Elizabeth Tudball is a SOSE (Studies of Society and Environment) lecturer in the Faculty of Education, Monash University. Her research interests include Civics and Citizenship, Professional Learning Communities and Teaching and Learning in Social Studies. She is currently working on a 3-year project with the Australia Japan Foundation with Japanese Social Studies teachers. 


\section{Series Editor's Foreword}

This series in Teacher Education: Self-study of Teacher Education Practices (S-STEP) sets out to illustrate a range of approaches to self-study of teaching and teacher education practices and to highlight the importance of teachers and teacher educators taking the lead in reframing and responding to their practice in order to foster genuine educational change. The series will complement the International Handbook of Self-study of Teaching and Teacher Education practices (Loughran, Hamilton, LaBoskey, \& Russell, 2004) and create strong examples of self-study that will further define this important field of teaching and research.

As self-study is generally initiated by, and focused on, teachers, teacher educators and the relation to their students (Bullough \& Pinnegar, 2001), there is an inevitable necessity to determine whether or not practice is consistent with the evolving ideals and theoretical perspectives espoused by participants. The research is improvement-aimed; participants wish to transform themselves first so that they might be better situated to help transform their students and the institutional and social contexts that surround and constrain them. Hence, self-studies of teacher education practices commonly demonstrate strong links between teaching, learning and program organization (and structure) as a search for enhanced teaching and learning about teaching is pursued. Not surprisingly then, Hoban's notion of The Missing Links makes an excellent beginning point to launch the series. In this book, Hoban offers a conceptualization crucial to the "what", "how" and "why" of teacher education programming.

\section{THE MISSING LINKS}

As Hoban makes clear in chapter one, the need to develop quality teachers in order to enhance the teaching and learning of students inevitably requires a close scrutiny of the ways in which teachers are educated about teaching and learning. Hoban does not suggest that his conceptualization is the one and only true way to consider the nature of teacher education programs. But, what he does do is draw particular attention to the purpose of teacher education and to remind us of the importance of responding to the complex nature of teaching and learning about teaching. 
Hoban illustrates how research consistently concludes that a "conventional" approach to teacher education programming has little influence on the way that student teachers come to view teaching; much less impact their practice. Rather, what he suggests is that instead of focusing on the individual elements of a teacher education program that there is a need to pay much more attention to design. In so doing, he begins to articulate his multi-linked approach to teacher education design argued on the basis of teaching as a complex profession that can be neither taught, nor learnt, simplistically.

The way in which the book is structured then examines in detail each of the four nominated links that together comprise a coherent conceptual framework for teacher education program design. The four links are:

- conceptual links across the university curriculum;

- theory-practice links between school and university settings;

- social-cultural links amongst participants in the program;

- personal links that shape the identity of teacher educators.

Each of the links is illustrated through exemplars derived from studies in "real" teacher education programs where the issues under consideration are analyzed and portrayed in such a way as to build a solid understanding of the link itself. At the end of each section, the studies that have been used to illuminate important aspects of the particular link are then distilled into a coherent whole to more fully display the nature of that link for the reader.

The four links then frame the book as they help to bring to life the separate design features that, when combined, promote coherence in a teacher education program. Importantly, Hoban argues that by focusing on the links rather than the independent elements (that are so often the main area of attention in teacher education programs), that the dynamics of teaching can best be learned. Hence, through his conceptualization, the complexity of teaching and learning about teaching is more fully realized and the value of the knowledge of teacher education practices begins to stand out as crucial to the valuing of teacher education itself.

Although the book is set out in a logical and progressive fashion, this is not to suggest that it needs to be read from cover to cover in a linear fashion. Clearly, an interest in any of the four links is not negated by the need to read all that precedes, or follows, that link. In fact, the studies that combine to instantiate each of the links are, of themselves, interesting and insightful examinations of particular approaches, ideas and practices in teacher education. Thus, each of the chapters can indeed be read as stand alone studies in their own right just as the four links also stand alone as coherent and meaningful on their own. Yet, it is in combination that teacher education design is fully realized 
and able to be appropriately responded to in a manner commensurate with Hoban's aspirations for the book as a whole.

Because Hoban maintains a strong focus on the individuals within a teacher education program (students, teachers and teacher educators), he (and his chapter authors) constantly remind us of the importance of the "self" and how it is that in educating the "self" that real insights into the complexity of teaching might emerge. Just as Berry (2004) draws attention to the notion of tensions in teaching and learning about teaching that are derived from understanding teaching as problematic, so too Hoban continually draws us back to the complexity of teaching to remind us of the difficulties created when applying simple solutions to intricate problems. And, it is on this basis that perhaps many of the "conventional" teacher education program structures and practices falter and why conceptualizing teacher education through a multi-linked approach is so important.

Hoban is not inherently critical of the good work and fine efforts of so many involved in, and concerned for, the world of teacher education. Rather, what he attempts to do through this book is to create an agenda for meaningful change so that the hopes and aspirations of all involved might be more fully realized.

Currently, it could well be argued, that teacher education reform is hampered by the predominance of a structural approach predicated on making the most of that which already exists; despite the obvious inadequacies. Hoban invites us to see the problem from a different perspective, to reframe (Schön, 1983) the situation and to approach it as one in which dynamic, as opposed to disconnected learning is pre-eminent.

There can be little doubt that by concentrating on Hoban's four main links that genuine program coherence might be achieved. Yet, importantly, it is the social and cultural connections that he is personally drawn to highlight. In binding the links so that a teacher education program coherently holds together, the connections between participants (teacher educators, student teachers and teachers) matters because of the ongoing influence of identity formation. Because social interaction between participants so dramatically impacts on relationships and practice, and if program design is to be dynamic and responsive to the complexity of the profession of teaching, then this link is one that can not be overlooked, or worse, avoided, in program design. Moreso, what Hoban would argue, is that the social and cultural connections need to be strengthened - for if this link is sufficiently tempered, program coherence will more likely be achieved.

In this book Hoban has forged the links that comprise his approach to designing teacher education programs. The scholars he has assembled and charged with explicating particular aspects of his links help to demonstrate 
the extent to which research in teacher education is advancing. Such advancement is in response to the growing concern of participants for enhanced learning outcomes in teaching and learning about teaching; and is becoming increasingly evident internationally. Not surprisingly then, many of Hoban's chapter authors are themselves leaders in the field of self-study of teacher education practices $(S-S T E P)$ as their personal involvement in, and concern for, teacher education drives their own research and practice; and the emerging research agenda for teacher education itself.

It seems obvious then that this book, with so much to offer the world of teaching and learning about teaching, is most appropriate to launch a series that is designed to positively challenge the work of teacher education. I have great pleasure in commending this book to you and trust you find it not only interesting and thought provoking but that it becomes a catalyst for the development of coherent teacher education program redesign in your setting.

Research that influences practice and practice that influences research; that is an agenda worth pursuing. Hoban has offered the invitation, how do you choose to respond?

\section{J. John Loughran}

\section{REFERENCES}

Berry, A. (2004). Self-study in Teaching about Teaching. In John Loughran, Mary Lynn Hamilton, Vicki LaBoskey \& Tom Russell (Eds.), International Handbook of Self-study of Teaching and Teacher Education Practices. (pp. 1295-1332). Dordrecht: Kluwer Academic Publishers.

Bullough, R.V. Jr., \& Pinnegar, S. (2001). Guidelines for quality in autobiographical forms of self-study research, Educational Researcher, 30 (3), 13-21.

Feiman-Nemser, S., and Floden, R. (1986). The Cultures of Teaching. In M.C. Wittrock (Ed.), Handbook of Research on Teaching ( ${ }^{\text {rd }}$ ed., pp. 505-526). New York: Macmillan.

Loughran, J.J., Hamilton, M.L., LaBoskey, V.K., \& Russell, T.L. (Eds.) (2004). The International Handbook of Self-Study of Teaching and Teacher Education Practices (Volumes 1 \& 2). Dordrecht: Kluwer Academic Publishers.

Schön, D.A. (1983). The reflective practitioner: How professionals think in action. New York: Basic Books.

Zeichner, K. (1999). The new scholarship in teacher education. Educational Researcher, 28(9), 4-15. 